Марија Митровић

Универзитет у Трсту

marmitrovic41@gmail.com

Marija Mitrović

Università degli studi di Trieste

marmitrovic41@gmail.com

\title{
ФУНКЦИЈА ПИСМА У ПРОЗИ ЈЕЛЕНЕ ДИМИТРИЈЕВИЋ
}

\section{THE ROLL OF THE EPISTOLARY FORM IN THE PROSE OF JELENA DIMITRIJEVIĆ}

У средишту пажње овога рада јесте једна формална карактеристика коју Јелена Димитријевић често користи: епистоларна форма је изузетно важна и честа, особито у њеној раној фази. Ова се ауторка јавила као песникиња (1894), али се са преласком на прозне форме (1897) она ослонила на епистоларну форму, верујући да ће јој иновације унутар саме те форме омогућити да у модерној српској књижевности која је тада тек била на помолу заузме посебно, друкчије и свакако заслужено место. То се, међутим, тада, у њено доба и за њеног живота није догодило. Али би сада, када је ова ауторка ипак коначно уврштена и у школску лектиру вредело да ишчитамо и те квалитете њене доиста традиционалне, али њеном руком иновиране форме, односно функције писама.

Кључне речи: Јелена Димитријевић, епистоларна форма, документарност.

This essay deals with the importance of the epistolary form in the prose of Jelena Dimitrijević. This Serbian writer started as a poet (1894), but soon shifted to prose (1897) especially fond of publishing correspondence, believing that only the innovations within the epistolary form could grant her the relevance she undoubtfully deserved within Serbian literature. Although such recognition did not happen during her lifetime, today, when her works are recognized within the Serbian literary canon and became manatory readings in schools we need to take a deeper look at this, in origin, very conservative form of writing, but a form of writing to which she gave a new and original contribution, i.e. the prose in the form of letters.

Keywords: Jelena Dimitrijević, epistolary form, literature as a document.

Од како је Јелена Димитријевић „откривена“ као плодна ауторка чије дело савршено комуницира са савременим феминистичким и постколонијалним теоријама, она не престаје да привлачи пажњу интерпретатора. Један од несумњиво кључних текстова, објављен у више вари- 
јанти и на више језика ${ }^{1}$ јесте завидно документована студија Светлане Слапшак „Харем, номади: Јелена Димитријевић“. Своје истраживање С. Слапшак завршава реченицом: „Закључујем овај сумарни увид у могућности тумачења њенога дела са жаљењем што је то дело сувише чекало“ (Слапшак 2000: 73).

Последњих двадесетак година дело Јелене Димитријевић привлачи и пажњу издавача: објављена су поново готово сва њена дела која су била штампана за њеног живота, а из рукописа се 2020. године у штампаном облику појавио и други том њеног путописа Седам мора и иири океана. Бројне студије, магистарске или докторске дисертације читају Јелену Димитријевић у светлу gender studies, баш како је то пред истраживаче као задатак поставила С. Слапшак у већ наведеној студији у следећој реченици: „Јелена Димитријевић ставља своју заоставштину јединој интерпретацији која јој неће нанети неправду — феминистичкој“(Ibid.).

Моју пажњу је, међутим, привукла једна формална карактеристика коју ова ауторка често користи. Наиме, свако ко стекне ма и површан увид у прозу Јелене Димитријевић лако у њој уочава доминацију епистоларне форме, особито у њеној раној фази: од 12 књига које је објавила за живота, чак четири садрже у наслову реч „писма“, а и читав низ, односно серије писама објавила је ова ауторка у књижевним часописима свога времена. Тачно је да је „мешавина писмо-путопис уобичајена за женску књижевност“ (Слапшак 2000: 50), али се чини да се ова ауторка баш на епистоларну форму ослонила верујући да ће јој иновације унутар саме те форме омогућити да у модерној српској књижевности која је тада тек била на помолу заузме посебно, друкчије и свакако заслужено место. То се, међутим, тада, у њено доба и за њеног живота није догодило. Али би сада, када је она ипак коначно уврштена и у школску лектиру вредело да ишчитамо и те квалитете њене доиста традиционалне, али њеном руком иновиране форме, односно функције писма.

Јелена Димитријевић чита се данас са задовољством свакако и зато што њена проза доноси живу онтолошку слику стварности доба и средине у којој живи или је упознаје као путница. У Ниш се она преселила само три године након што је та варош поново постала српска. Град ју је привлачио у оном сегменту који је тада, у фази формирања самосталне српске државе, био потискиван у заборав. „Државни национални програм заборављања турске културе и темељног уништавања трагова искључује још пре почетка њен напор описивања и допринос знању: такво знање није више потребно“ (Слапшак 2000: 56). Нема сумње да је аутор-

1 Објављен је први пут у часопису ПроФемина (15/16 (1998): 137-149), потом и у књизи Жене, слике, измищльаји (ур. Бранка Арсић, Центар за женске студије, Београд 2000), док је на енглеском језику он доступан на сајту ("Harems, Nomads: Jelena Dimitrijević", http://www.zenskestudie.edu.rs/izdavastvo/elektronska-izdanja/istrazivanja/ zavera-necitanja/62-harems-nomads-jelena-dimitrijevic). 
ка била свесна овог потискивања турске културе. Светлана Томић ${ }^{2}$ чак упозорава да се Ј. Димитријевић својим путописно-прозним делом Писма из Нища о харемима (1897) директно супротставила слици коју је о жени исламске културе успоставио у свом путопису С Мораве на Вардар (1894) тада велики ауторитет не само у култури него и у политици, Стојан Новаковић. Неминовно је онда упитати се: којим средствима, каквом техником писања је Јелена Димитријевић не само доказала да је описивање брисаних сегмената из живота женског исламског света на тлу Србије потребно. Своје прво прозно дело она у целини гради баш на слици исламске културе каква се испољавала у приватном животу турских жена у Нишу у време када је она тамо живела.

Bећ на почетку првог, од укупно 16 писама колико их садржи прва Јеленина проза Писма из Нища о харемима (1897) ауторка истиче да постоје читаоци који од ње очекују баш то: слику живота жена, посебно турских, у вароши у коју се она доселила. Сва су писма упућена пријатељици Н, а ауторка јој се обраћа са „Мила моја Н“. „Није ми једном прозборила сирота M, моја другарица из детињства кад се знало да ћу живети у лепом Нишу. 'Упознај се с булама; види њихове обичаје, нарочито свадбене, опиши их...'“ Пријатељство из младости описано је као дубоко, две се особе растају плачући: „И она је плакала, грлила ме, молила ме да јој често пишем, о себи, о Нишу и - о булама. Учинила сам јој по вољи: упознала сам се с булама брзо - само њој за љубав. Али, ах, ње одавно нема...“ Па сада опис свега онога што је требало да саопшти покојној пријатељици М, она упућује пријатељици Н. Јер, зна се, завет је завет, особито када је дат особи која више није међу живима. Тај етички кодекс, жив још и данас особито у традиционалној балканској култури, ауторка је ставила на сам почетак ове своје прве прозе. Ваља тај податак узети озбиљно. Па иако ће писма са својих путовања упућивати живим особама, необично је важно то што Јелена Димитријевић истиче да се ради о пријатељицама. Њима она „дугује“ истину, што стварнију слику виђенога; пријатељство обавезује.

Није важно да ли је описана ситуација која је стављена на ударно место, на сам почетак прве објављене прозне књиге стварна или измишљена, али је несумњиво оваквом формулацијом Јелена Димитријевић успоставила писмо пријатељици као кључну формулу, јак аргумент и незаобилазно „оправдање“ изношења скривеног, непознатог, а стварног света у који је приспела.

Првом својом прозном књигом Јелена Димитријевић је скренула пажњу читаоцу да њена писма имају неку мисију, неку важну улогу. Фор-

2 Svetlana Tomić, „The Travel Writings of Jelena Dimitrijević: Feminist Politics and Privileged Intelectual Identify“. Bogdanović J., Filipovich I., Marojević I. (ed.). On the Vey Edge - Modernism and Modernity in the Arts and Architecture of Interwar Serbia (19181941). Lueven: Lueven University Press, 2014: 115-133. 
ма писма пријатељици какву је Јелена Димитријевић на овом месту изабрала и експлицитно јој доделила, даје тој форми готово свету улогу: нарација таквог писма мора бити одговорна, искрена, профињена, поуздана... Причање, приказивање живота муслиманских жена у њиховој приватности, као и изношење стварне, никако не стереотипне слике тог муслиманског света је нешто на шта списатељку обавезује покојна пријатељица. У доцнијој путописној прози, пријатељица више неће бити покојна, неће се спомињати ни њен завет, али ће остати јасно записано да се ради о пријатељици и одговорном односу према пријатељству. Кроз свих 16 писама из Ниша тај се описан женски свет открива као комплексан, препун тајни. Непознат, скрајнут. Али баш по тој скрајнутости, изолованости он се заправо ипак доима не само као живот муслиманске жене, него као живот жене уопште; он све више постаје симболична слика живота жена као таквих. Јер све су тада биле у сенци, сведене на приватни живот.

Већ у свом првом прозном делу ауторка нуди, дакле, кључ сопственог поимања писма као књижевне форме за коју се, као доминантну, сама определила. Она се својим писмима обраћа пријатељицама, често сазнајемо њихова права имена и презимена, место и датум писања писама. Све то као да сугерише да оно што описује јесте објективно, достојно поверења блиских особа. Пријатељица као адресат је нека додатна гаранција ауторкине жеље да комуникација сведочи о догађајима које је сама ауторка видела и доживела. Чини се да је то начин „правдања“ покушаја преношења баш оне слике, оне стварности коју тадашња пракса одбацује. Она зато истиче да њене читатељке, њене пријатељице желе баш ту, стварну слику свакодневног живота која у моменту стварања нације није била пожељна.

Када је стигла у Ниш, ауторка је пажљиво проучавала живот, посебно свет муслиманки, како би након 15 година боравка у том граду објавила књигу која приказује свакодневну културу муслиманских жена у харему и то са огромном емпатијом.

У есеју „Између чињенице и фикције. Писмо и епистоларна проза“ Магдалена Кох с правом примећује да већ у овом делу ауторка „двоструко нарушава тематске табуе српске књижевности. Најпре то чини као Српкиња очарана турском културом, коју њени сународници традиционално углавном из политичких, историјских и верских разлога - третирају као непријатељску /.../ Јелена Димитријевић прелази границе и као жена која пише о муслиманкама из перспективе 'туђинке', посвећене аутсајдерке која открива тајну њиховог живота“ (Кох 2012: 148). ${ }^{3}$ Тиме

3 У тексту који је Магдалена Кох објавила на енглеском језику заједно са Биљаном Дојчиновић (Dojčinović B., Koch M., „Turkish in Cyrillic: Deep Transgression in Jelena Dimitrijević's Writings.“ (текст је доступан на: http://www.knjizenstvo.rs/sr/casopisi/2017/ zenska-knjizevnost-i-kultura/turkish-in-cyrillic-deep-transgression-in-jelena-dimitrijevic-swritings\#gsc.tab=0) појављује се термин „deep transgression“, али се он не односи на ово 
што описује интимни живот муслиманки она угрожава приватност жена заклоњених зидовима харема.

Писање писама се у овом првом прозном делу наше ауторке показало као неминовно, као ефикасан кључ за оно што је писањем наумила да предузме ова енергична жена, борац за људска, а пре свега женска права. Изнађена формула очигледно је комуницирала са тадашњим читаоцем, отварала јој врата и чинила је одмах, у старту, списатељицом од успеха, како код читалаца, тако и код издавача. Мање код књижевних критичара и историчара књижевности. Света је дужност ауторке да писмо испуни садржајем који је поуздан, који је верно сведочанство оног хоризонта који се новопридошлој Нишлијки отворио када је у тај град дошла. Тек новије студије ${ }^{4}$ откривају како је у овом свом првом прозном делу Јелена Димитријевић натукнула, наговестила, инсинуирала на бројним местима да у харему спонтано настаје и донекле се испољава моносексуална љубав, да су бројне жене упућене на сексуалну наклоност према истополним особама; у недостатку мушког света, а у ситуацији када музика, песма, посебне припреме за свадбене свечаности некако покрећу сва чула и све страсти, испољава се и та забрањена, „грешна“ љубав. И ауторка успева да је управо као такву и прикаже: као спутану, само наговештену али несумњиву, постојећу, упркос суспрезању.

Дакле, није ова ауторка са огромним емпатијама само приказала осећања и расположења, обичаје и песме турских жена из Ниша, она је ствар нечувена у то доба - инсинуирала, сугерисала да се међу тим женама одвија, истина суспрегнута, верским законима блокирана, али ипак назначена, изречена бојом гласа, гестовима испољена лезбејска љубав.

Постоји још један аспект ове прозе објављене пред сам крај XIX века који и данас мора привући пажњу читаоца и тумача: необично је велики број турских речи, читаве синтагме, па чак и наслови појединих поглавља исписани су на турском језику. Сигурно је у праву Светлана Слапшак када истиче:

„прелазак на други језик, чини ми се, најубедљивији доказ напуштања доминантног дискурса $<\ldots$..> Њени сувремени читаоци из старога краја или из новоосвојених подручја морали су гледати на њен језик као на чисти изазов, али се Јелена Димитријевић у томе случају спасавала још једном техником колонијалног дискурса: егзотизацијом, комбиновањем завођења и нејасности“ (Слапшак 2000: 57).

нарушавање тематских табуа о чему је у овом раду реч, него на резултате суочавања Истока и Запада, што је присутно у сасвим благој форми у Писмима из Нища (1897), појачава се у Писмима из Солуна (1908), да би кулминирало и доиста се могло означити као „deep transgression“ у роману Нове (1912) .

4 О овој теми видети студију: Јована М. Реба, „Род и трансвестија у харемском

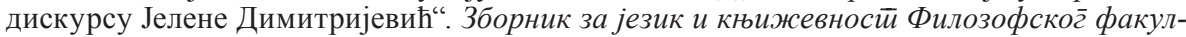
йейа у Новом Саду. Књига I (2011): 205-215. 
Но, чини се да је легитимно упитати се није ли можда и ово екстремно наглашено присуство турског језика у тексту имало какву симболичну функцију? Јелена Димитријевић је баш у жељи да што боље упозна живот турских жена учила и научила турски језик. То што је тај податак оваквом честом употребом турских израза она желела да поткрепи, она као да је уз то желела да покаже да је језик за њу мост, могућност успостављања блиског односа са турским женама из харема. Ако је као особа која не припада муслиманској култури, а открива тајне приватног живота иза зидова харема, она повредила приватност ових жена, овим језичким приближавањем турским женама она као да ублажава свој „грех“, своју некоректност која се огледа у изношењу у јавност оног света који је закључан и постоји само унутар зидова харема, није доступан очима странаца, па ни странкиња. Усвајањем турског језика, Јелена Димитријевић постаје мање странкиња, њен „продор“ у тајне света харемских жена није баш сасвим продор страног ока у тај свет; њено око је, захваљујући турском језику који је научила, био и део њиховог света. Језичка идентификација учинила ју је мање странкињом, мање аутсајдерком него што она то јесте била. Коришћењем бројних турских речи у тексту она жели да изрази блискост са женама чији живот открива. С друге стране, она том поплавом турских речи на још један начин пружа читаоцу гаранције да су њена писма — документи, да се она, захваљујући познавању њиховог језика, доиста толико приближила турским женама да нам о њима саопштава „голу истину“, баш ону и онакву слику какву јој је у задатак поставила њена (стварна или измишљена) пријатељица из детињства које више нема.

Постоји још један детаљ карактеристичан за поетику какву је изабрала Јелена Димитријевић у свом првом прозном тексту. На тај детаљ пажњу скреће Слободанка Пековић у предговору за фототипско издање Писама из Нища 5 она пише:

„Јелена Димитријевић је познавала оријенталну књижевност и књиге муслиманских путописаца о нашим крајевима. Пишући китњасто, са много деминутива који данас сметају читаоцу, она је заправо о Туркињама писала њиховим сопственим језиком. Сама каже да „Мусломанке“ много воле деминутиве, па се чини и логичним да када пише о Муслиманкама и говори на њихов начин. Зато су и описи који подсећају на приповедање из Хиљаду и једне ноћи, честа употреба стихова којима се илуструје приповедање, један од начина уживљавања у атмосферу“" (Пековић 1986: XII).

Осим турског језика и ова имитација стила писања карактеристичног за дела настала унутар оријенталних, пре свега муслиманских кул-

5 Цитат је са стр. ХІІ студије „Јеленина писма“ у фототипском издању из 1986. Налази се на адреси: https://ia802605.us.archive.org/0/items/pismaizniaohare00pekogoog/ pismaizniaohare00pekogoog.pdf 
тура свакако је био и вид успостављања моста са женама, чији је интимни свет она износила у јавност. На истом месту одакле је цитиран овај исказ о преузимању оријенталног стила, Слободанка Пековић наводи и низ примера којима илуструје својеврсну банализацију приповедања:

„Кад описује унутрашњи живот Туркиња Јелена Димитријевић заборавља на своју улогу објективног посматрача и дозвољава своме сентименту да се потпуно искаже. Уцвељена млада као да је јунакиња из дела Јанка Веселиновића или Чедомиља Мијатовића. Сликајући њена осећања списатељка се служи стереотипима и клишеима који су с једне стране, блиски нашем културном наслеђу јер се препознају у народним песмама (сунашце сјајно, ево једва земан дође и слично), али и онима који су тривијални и који само оптерећују текст <...”“ (Ibid.).

Али шта ако је и ово имитирање баналног, свакодневног, клишетизираног стила такође у функцији стилског приближавања свету жена које у свом роману описује? Уосталом, и сама С. Пековић завршава наведени цитат овако: „Ипак, овакав начин писања би се могао објаснити жељом да се предмет оживи изнутра, да се уђе иза постављене баријере и да се описане ствари проосећају, да се прикажу саме собом“" (Ibid.).

Наставимо ли размишљање у правцу који смо зацртали и који нас води ка уочавању свих оних техничких детаља који могу допринети уверљивости, документарности слике света који нам списатељка у овој прози приказује, онда ће можда и оваква претпоставка записана на крају одломка који наизглед оптужује ауторку за баналност, споменуту стилизацију учинити функционалном.

Можда се у овом часу вреди подсетити једног од темељних теоретичара књижевности XX века, Михаила Бахтина који је пратио процес настајање модерне вишегласне литературе од раних фолклорних модела, преко класичне гротеске и сатире, па све до модерне дијалогичности текста која се постиже техником писања, међусобним супротстављањем, слагањем плоха различитих језика, од дисикурзивног до недискурзивног, од документа до фикције. Говор другога, његов аутентични ток и звук такође су један од стубова дијалогичности коју Бахтин види као суштинску одлику модерне литературе. Прво прозно дело које је Јелена Димитријевић објавила садржи несумњиво назнаке, упуте, кључеве коришћења форме (за њу су то писма пријатељицама) као вида усложњавања слике света који жели да прикаже. ${ }^{6}$ И још: ту сложеност, вишегласност модерне прозе она је настојала да постигне и укључивањем говора, јези-

6 У студији „Фолклорне основе Раблеовог хронотопа“ Михаил Бахтин узима Достојевског као писца који је први у потпуности умео да гради реч јунака тако да он сам собом изнесе вишеструку истину света. Јелена Димитријевић је на некој нижој, али важној степеници поимања функције језика својих јунакиња у циљу усложњавања слике света чији су оне део. 
ка тог света који описује, као и прозних литерарних модела који су се користили, који су били присутни у исламској култури на Балкану.

Зашто је овој ауторки било толико стало да своја писма састави и читаоцу предочи као стварну слику једне блиске, али непознате стварности?

Јелена Димитријевић започела је своју књижевну каријеру као песникиња: године 1894. изишла је њена збирка, под једноставним насловом: Песме. Но, иако је поднаслов ове прве Јеленине књиге био: „Књига I“, она никада није објавила другу књигу својих песама. Свој прозни првенац, књигу компоновану од 16 писама, она жели да окарактерише као прелом, као заокрет: она се више не задовољава фиксирањем и у стихове преточеним сликама властитих осећања, нити откривањем личног, интимног света. Она литературу сада види као сведочење о једној стварности, која је ту, поред нас, а нама је сасвим непозната. Дакле, она прави рез, не жели да се њена проза означи као „женска“ у оном смислу у којем је тада та књижевност и била означавана као женска, јер лична, интимна, сентиментална, уколико није била народска, поучна, патриотска.

Прелазећи са поезије на прозу она је, за њу нов књижевни род настојала да формулише и нову поетику: проза је за њу сведочење о простору и времену, о ономе што окружује ауторку. То је дакле идеал који Јелена Димитријевић себи поставља у српској прози на крају XIX века. При том се ваља присетити да је женском писму дуго било негирано право писања и објављивања текстова који би се читали као слика времена. Тек године 2001. објављена је, на пример, књига сећања Mоје усйомене Савке Суботић (1834-1918), која је живела у Новом Саду, припадала угледној породици и била супруга адвоката, политичара и писца Јована Суботића. Станка Глишић (1859-1942), сестра Милована Глишића, успела је 1933. да објави своје Усйомене, захваљујући баш фондацији „Милован Глишић“, али је рецепција те књиге била више него лимитирана, заправо никаква. Како истиче Светлана Томић, ${ }^{7}$ док су мемоари писаца с краја XIX и почетка XX века објављивани и више пута, у више издања, женски мемоари су остајали у рукопису, а историографија се ретко или никако не позива на женске мемоаре, иако су они богати извори и сведочења о социјалном животу свога времена. Није било предвиђено да проза као сведочанство настаје испод женске руке. ${ }^{8}$

7 Svetlana Tomić, "Rediscovering Serbian Women's Memoirs: Gendered Comparison in a Historical Context": Textie drugie 1(2020): 124-139. Special Issue English Edition: Convention and Revolution, ed. by Monika Rudaś-Grodzka, Katarzyna Nadana-Sokołowska, Anna Nasiłowska, Karolina Krasuska, and Emilia Kolinko. Tekst je dostupan na adresi: http:// tekstydrugie.pl/wp-content/uploads/2020/07/teksty-drugie-tom-1.2020.pdf

8 Речит пример занемаривања женске документарне прозе је и чињеница да у Нолитовој едицији „Српска књижевност - мемоари, аутобиографије, дневници, која је у 25 томова објављена 1988-1989. године ниједна ауторка нема посебну књигу! Два женска имена - Милица Стојадиновић Српкиња и Мина Караџић - заступљена су 
У овом контексту одлука Јелене Димитријевић да своју прозу обликује као што објективнију слику спољашњег света јесте несумњиво доказ о томе да она бира један свој, нови пут излажења из схеме онога што се до тада, а и дуго потом подводило под појам „женска књижевност“. Тиме што се одлучила да користи писмо као опробани „женски“ жанр, она је свакако могла привући публику; но, интелигентно и инвентивно, она је ту форму - слободно можемо рећи - револуционисала, користила не за преношење личних доживљаја и осећања, него за приказивање новог, а старог света, за стварање аутентичне слике живота муслиманских жена.

Њена свесно грађена поетика писама сјајно се потврдила у књизи Писма из Солуна (1908, а као књига 1918). Прецизније: Јеленина писма Луизи Јакшић, писана из Солуна од 2. августа до 11. септембра 1908. одмах су осванула у Срйском књижевном глласнику (1908-1909), тада свакако најзначајнијем књижевном часопису. Тачно сто година касније, 2008. једно графички скромно, али двојезично српско-грчко издање ове књиге, ${ }^{9}$ привукло је пажњу најпре грчке књижевне средине, а онда је дошло и до превода на италијански, ${ }^{10}$ где је књига доживела завидну рецепцију. ${ }^{11}$ У Писмима из Солуна добијамо аутентичне описе и детаљна објашњења појединих појава које су се дешавале у Солуну почетком $\mathrm{XX}$ века. ${ }^{12}$ Књигу Писма из Солуна прихватила је и ондашња, а и данашња публика као драгоцени, литерарно написани документ о једном граду и једном историјском догађају, али сагледаном из женске перспективе.

И роман Нове (1912) користиће, осим објективног приповедања у трећем лицу, још и писма како би постигла „илузију аутентичности епског догађања у целини“ (Стјеља 2012: 129). А током двадесетих година Јелена Димитријевић ће објавити још читаву серију писама, од којих су нека (она из Индије и она из Мисира) касније укључена у њене путописне књиге, док су друга (из Атине, Тракије, Лондона и Париза) остала необјављена у књижевном опусу ове списатељице, иако су и та путописна писма на завидном литерарном нивоу.

у овој едицији са кратким одломцима само у два тома насловљена Мемоарска ирроза XVIII и ХІХ века.

9 Издавач је „Карпос“ из Лознице, а уредници Дејан Аничић и Владимир Бошковић; књига је објављена у свега 400 примерака.

10 Lettere da Salonicco. Vita activa, Trst, 2018.

11 У тршћанском дневном листу лепу рецензију књиге написала је проф. Кристина Бенуси (Benussi: Il Piccolo od 15. фебруара 2019); рецензија Лауре Рићи (Ricci) може се наћи на овој адреси: https://www.letteratemagazine.it/2018/12/16/uninviata-negli-harem-di-Salonicco/\#: : text $=$ Poeta $\% 2 \mathrm{C} \% 20$ viaggiatrice $\% 20 \mathrm{e} \% 20$ scrittrice $\% 2 \mathrm{C} \% 20$ poliglotta,quali\%20ha\%20vis suto\%20e\%20operato. Једна оцена Натке Бадурине биће објављена у најзначајнијем славистичком часопису у Италији, Studi slavistici ...

12 Професорка новогрчког језика и литературе Луција Маркезели (Marcheselli) са Универзитета у Трсту изјавила ми је након читања грчког превода да је књига Ј. Димитријевић најбољи водич кроз социјална стања Грчке с почетка XX века. 
Резултате својих драгоцених и веродостојних запажања из једногодишњег боравка у „новом свету“, односно Америци, ${ }^{13}$ ауторка није више слагала у фрагментарну структуру писама, иако је на крају књиге осетила потребу да нагласи да књиге не би било да она није писала писма својим пријатељицама:

„Нови свет сам написала под непосредним утисцима и по опажањима онда кад је мени Њујоршка лука била 'лука заборава'; а слала сам одломке или писма драгим пријатељицама — којима посвећујем ово своје дело госпођи Јоки Петровић Његош — сада на велику жалост покојној — и госпођи Делфи Ив. Ивановић, оснивачици Кола српских сестара и његовој првој потпредседници“ (Димитријевић 2019: 44-45).

Од путовања до објављивања књиге прошло је много времена (путовала је 1919-1920, а текст објавила 1934), али се ауторка тада када је књигу објавила осећала и те како сигурном у свом путописном жанру као документу о социјалном, антрополошком и етнографском животу људи у земљама које је посетила да више није било потребе да у текст копира писма као документе који гарантују истинитост, озбиљност, објективност слике приказаног света. Али је цитат који смо овде навели потврда чињенице да је сама ауторка себе доживљавала као особу која најбоље пише у првом, непосредном, живом сусрету са новом стварношћу. Јелена Димитријевић је доиста списатељка која уме да ухвати прави тренутак, да га заустави и забележи. Детаљи касније испаре, нестају... Писма која пише Јелена Димитријевић имају унутар поетике какву је изградила вишеструки задатак: да пренесу ону слику света која је најаутентичнија, која се створи у тренутку, у часу првог сусрета са новим светом. Белешка коју у овом случају ставља на сам крај путописа из Америке још једном истиче значај чињенице да су ти утисци своједобно били упућивани пријатељицама. И опет, једне од тих пријатељица нема више, али тиме она још више обавезује ауторку да не измишља, да се држи истине, да пријатељице извештава о томе какав је тај свет које је она имала прилику да види, а оне да од ње чују што више детаља о виђеном.

Слично је и са путописом који је објављен у две књиге под насловом Седам мора и йри океана (1940. први том, а други том 2020. у електронском формату и као штампана књига). Писмо из Мисира, односно писма из Индије су некакав заметак овог последњег прозног дела, али са далеког Истока доиста тада није било ни техничких могућности слања писама у Европу, па је по свему судећи Јелена само бележила сусрете и догађања, али више није уобличавала утиске у писма.

Поетика приповедања Јелене Димитријевић била је прихваћена; она је читана као озбиљан, објективни путописац, који се обавести о земљама кроз које ће путовати још пре него што крене на пут. Она читаоца обаспе

13 Нови свет̄ или у Америции г̄одину дана. Beograd 1934. 
серијом података који су права ризница за проучавање тих далеких култура. Мишел Фуко (Foucault, 2015: 53) истиче да многи текстови заправо и немају аутора јер писац само преноси, копира моделе писања које су други створили. Према Фукоу, аутор/ауторка неког текста је она особа која је у стању да смисли и реализује сопствени концепт писма (у ширем смислу ове речи). Јелена Димитријевић ту титулу несумњиво заслужује својом способношћу да користећи често епистоларну форму читаоцу преносе дискурс који уважава законе вероватности и стварног збивања. Што је било сасвим ново унутар дотадашње српске женске прозе.

\section{ЛИТЕРАТУРА}

Димитријевић Јелена. Писма из Солуна. Двојезично издање. Лозница: Карпос, 2005.

Димитријевић Јелена. Нове. Београд: Службени гласник, 2012.

Кох Магдалена. ...када сазремо као кулимура... Сйваралащйво срйских сииисайељииа на йочейку XX века (канон - жанр - род). Београд: Службени гласник, 358 стр.

Реба М. Јована. „Род и трансвестија у харемском дискурсу Јелене Димитријевић“. 3бор-

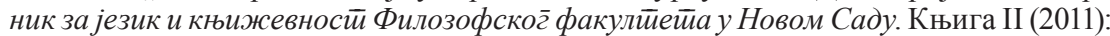
205-215.

Стјеља Ана. Елеменӣи ӣрадищионалног̄ и модерног̄ у делу Јелене Димийријевић. Докторска дисертација. Београд 2012. 226 стр.

Bahtin Mihael. „Folklorne osnove rableovskog hronotopa“. Savremenik 12 (1985): 520-534.

Dimitrijević Jelena. Pisma iz Niša o haremima. Fototipsko izdanje: Beograd - Gornji Milanoviac: Dečje novine, 1986. <https://ia802605.us.archive.org/0/items/pismaizniaohare00pekogoog/pismaizniaohare00pekogoog.pdf>

Dimitrijević Jelena. Novi svet ili godinu dana u Americi. Beograd: Laguna, 2019.

Dojčinović Biljana, Koch Magdalena. „Turkish in Cyrillic: Deep Transgression in Jelena Dimitrijević's Writings“ <http://njnjnj.knjizenstvo.rs/sr/casopisi/2017/zenskaknjizevnost-i-kultura/turkish-in-cyrillic-deep-transgression-in-jelena-dimitrijevic-snjritings\#gsc.tab $=0>$

Foucault Michel. ,"Sto je autor?“. S francuskog prevela Nataša Medved. Zagreb: Jesenski e Turk, 2015. 77 str.

Peković Slobodanka. „Jelenina pisma“. Dimitrijević Jelena. Pisma iz Niša o haremima. Fototipsko izdanje. Beograd — Gornji Milanovac: Dečje novine, 1986: I-XV.

Slapšak Svetlana. „Harem, nomadi: Jelena Dimitrijevićc“. Branka Arsić (ur.). Žene, slike, izmišljaji. Beograd: Centar za ženske studije, 2000: 49-73.

Tomić Svetlana. "Rediscovering Serbian Women's Memoirs: Gendered Comparison in a Historical Context". Textie drugie 1(2020): 124-139. Special Issue English Edition: RudaśGrodzka Monika, Nadana-Sokołowska Katarzyna, Nasiłowska Anna, Krasuska Karolina and Kolinko Emilia (ed.). Convention and Revolution $<\mathrm{http}$ ://tekstydrugie.pl/ wp-content/uploads/2020/07/teksty-drugie-tom-1.2020.pdf>

Tomić Svetlana. "The Travel Writings of Jelena Dimitrijević: Feminist Politics and Privileged Intelectual Identify". Bogdanović J., Filipovich I., Marojević I. (ed.). On the Vey Edge Modernism and Modernity in the Arts and Architecture of Interwar Serbia (1918-1941). Lueven: Lueven University Press, 2014: 115-133.

\section{LITERATURE}

Bahtin Mihael. „Folklorne osnove rableovskog hronotopa“. Savremenik 12 (1985): 520-534.

Dimitrijević Jelena. Pisma iz Niša o haremima. Fototipsko izdanje: Beograd — Gornji Milanoviac: Dečje novine, 1986. <https://ia802605.us.archive.org/0/items/pismaizniaohare00pekogoog/pismaizniaohare00pekogoog.pdf $>$ 
Dimitrijević Jelena. Pisma iz Soluna. Dvojezično izdanje. Loznica: Karpos, 2005.

Dimitrijević Jelena. Nove. Beograd: Službeni glasnik, 2012.

Dimitrijević Jelena. Novi svet ili godinu dana u Americi. Beograd: Laguna, 2019.

Dojčinović Biljana, Koch Magdalena. „Turkish in Cyrillic: Deep Transgression in Jelena Dimitrijević’s Writings“ <http://njnjnj.knjizenstvo.rs/sr/casopisi/2017/zenska-knjizevnost-i-kultura/turkish-in-cyrillic-deep-transgression-in-jelena-dimitrijevic-s-njritings\#gsc.tab $=0>$

Foucault Michel. „Što je autor? “. S francuskog prevela Nataša Medved. Zagreb: Jesenski e Turk, 2015. 77 str.

Koh Magdalena. ...kada sazremo kao kultura...Stvaralaštvo srpskih spisateljica na početku XX veka (kanon —žanr — rod). Beograd: Službeni glasnik, 358 str.

Peković Slobodanka. ,Jelenina pisma“. Dimitrijević Jelena. Pisma iz Niša o haremima. Fototipsko izdanje. Beograd — Gornji Milanovac: Dečje novine, 1986: I-XV.

Reba M. Jovana. „Rod i transvestija u haremskom diskursu Jelene Dimitrijević“. Zbornik za jezik i književnost Filozofskog fakulteta u Novom Sadu. Knjiga II (2011): 205-215.

Slapšak Svetlana. „Harem, nomadi: Jelena Dimitrijević“. Branka Arsić (ur.). Žene, slike, izmišljaji. Beograd: Centar za ženske studije, 2000: 49-73.

Stjelja Ana. Elementi tradicionalnog i modernog u delu Jelene Dimitrijević. Doktorska disertacija. Beograd 2012. 226 str.

Tomić Svetlana. "Rediscovering Serbian Women's Memoirs: Gendered Comparison in a Historical Context". Textie drugie 1(2020): 124-139. Special Issue English Edition: Rudaś-Grodzka Monika, Nadana-Sokołowska Katarzyna, Nasiłowska Anna, Krasuska Karolina and Kolinko Emilia (ed.). Convention and Revolution $<$ http://tekstydrugie.pl/ wp-content/uploads/2020/07/teksty-drugie-tom-1.2020.pdf $>$

Tomić Svetlana. "The Travel Writings of Jelena Dimitrijević: Feminist Politics and Privileged Intelectual Identify". Bogdanović J., Filipovich I., Marojević I. (ed.). On the Vey Edge Modernism and Modernity in the Arts and Architecture of Interwar Serbia (1918-1941). Lueven: Lueven University Press, 2014: 115-133.

\section{Marija Mitrović}

\section{IL RUOLO DELLA FORMA EPISTOLARE NELLA PROSA DI JELENA DIMITRJEVIĆ}

\section{Riassunto}

Dal primo suo libro di prosa (Lettere da Nis sugli harem, 1897) che descrive la vita delle donne musulmane, J. Dimitrijević usa la forma epistolare come elemento cruciale nell'organizzare la narrazione. L'attenzione di questo saggio si concentra proprio sul primo libro perché vi si trovano le spiegazioni esplicite sul tipo delle lettere che lei intende usare nella sua prosa. In una specie di preludio, l'Autrice avverte il lettore che una sua amica, purtroppo già morta le supplicava di scriverle sulla vita e sulle abitudini delle donne musulmane. Siamo nell'epoca quando lo stato serbo appena liberatosi dal secolare giogo dell'Impero ottomano sente la cultura musulmana come nemica e perciò non è apprezzabile come tema negli scritti di qualsiasi tipo. Bisognava dimenticare tutto quello che apparteneva al "nemico". Città che J. Dimitrijević abitava oppure frequentava e descriveva nella prima metà della sua vita sono città orientali. Rispondere al desiderio, alla richiesta di una persona che non è più tra $i$ vivi ha il valore di un voto nella tradizionale cultura balcanica. E così l'Autrice trova un vero motivo per poter scrivere le lettere alle amiche e informare proprio pubblico su un tema non desiderato, cancellato dalla politica nel preciso momento storico. Sue prose, non solo odeporiche (Lettere dal Salonicco,1908) ma anche romanzesche descrivono mondo orientale (romanzo Nuove, 1912), usando forma epistolare come una specie di garanzia della veridicità della realtà descritta. Oltre alla forma epistolare, indirizzata alle amiche che si presentano interessate a sentire i fatti, l'Autrice usa nel suo primo libro non solo i turchismi, ma un numero enorme 
delle vere parole turche, scritte però in cirillico. Con questo voleva sottolineare suo rapporto empatico, emotivo verso le donne musulmane. Alla cultura "del nemico" si avvicina anche usando lo stile che caratterizzava appunti di viaggio e prosa degli scrittori ottomani che lei leggeva in lingua turca. Dopo aversi affermata come la scrittrice e dopo aver iniziato a descrivere i propri viaggi a occidente (negli Stati Uniti, 1919-1920) scrive ancora le lettere alle amiche, ma questo fatto è adesso presente solo in una nota alla fine del libro, mentre la forma epistolare non è più principale organizzatrice della narrazione.

Parole chiave: Jelena Dimitrijević, forma epistolare, scrittura documentale. 